\title{
Sociological Approach on Sports Ethics in a Context of Social Change
}

\section{Salomé Marivoet}

Faculty of Sports Sciences and Physical Education, University of Coimbra, Portugal

ABSTRACT

In exploring sports ethics as a sociological phenomenon, I have tried to demonstrate how alterations in the nomos of the field of competitive practices (in the sense of Bourdieu), have unexpectedly unleashed a chain of events that have ultimately weakened the ethical principles of modern sport, imposing contradictions upon the way these are manifested in practice. Our theoretical approach to ethics was developed from the contribution of Durkheim, Weber and Elias.

The universe of our study was the Portuguese reality during the Democratic state as a case study of the phenomenon. The information collected in our research has required different methods of analysis (qualitative and quantitative) and sources of data (official statistics, news from media, participate observation and interviews).

Of the changes that took place in the last quarter of the $20^{\text {th }}$ century in the Portuguese sports field, I have identified the inextricable interdependence of sporting, economic and symbolic dimensions as the main determining factor behind the victory-oriented approach to sporting action, which in turn has led to a radicalization of rival interests and an intensification of competition.

As a result of this, there have been changes in the ethos of sporting interaction, weakening the principle of fair play and leading to an increase in practices that undermine it. This has meant that refereeing has become much more difficult, with increased distrust in the fairness of the competition, a situation which is aggravated by cases of corruption and doping. In this context, actors and organizations have become more involved in the ethical regulation of their sport in the Portuguese society. As a result, regulation has become more flexible and open to negotiation, both through institutional channels, and through strategies of pressure and persuasion in the (highly mediatized) public sphere. Thus, contingent solidarities have been strengthened to the detriment of organic solidarities.

The growing distrust, together with the dynamics of surveillance and supervision launched in the 1990s, have also contributed to the activation of mechanical solidarities within groups with shared interests, in a context of opposition-confrontation or radicalization. This has been propitious to manifestations of collective violent revolt, and to the institution of forms of premeditated violence between some groups of ultra fans. Consequently, the 
undermining of ethical regularization has become even more visible, particularly in the field of top-level professional football.

In response to the specific nature of the ethical conflicts in the sports figuration, states have intervened at national and European level by enshrining ethical principles in the form of legal provisions, defining systems of sanctions and penalties. This has resulted in a weakening of the autonomy enjoyed by sporting organizations, a principle that ultimately derived from the freedom of sporting associative movement in civil society.

\section{Introduction}

In the current context of Modernity, ethics has acquired a much more central role, not only within the debate on the plausibility of principles, but also as regards the difficulties of establishing how far principles determine social practices. In this context, we aim to explore the various tensions operating upon sports ethics as a sociological phenomenon.

As Durkheim (1977 [1893], p. 47) argued, morality involves facts of a "vital order"; i.e. facts that ensure the survival of social groups, and which are therefore subject to change, particularly at times of important social transformations (such as is the case of contemporary societies of Late Modernity). Nevertheless, we should also bear in mind that societies are not unitary, as Simmel (1986 [1918]) and others have pointed out.

Although classic theorists like Durkheim and Weber gave attention to the question of ethics, knowledge in this field has developed in a somewhat fragmentary and unsystematic fashion, which hinders research. Moreover, there are also a number of obstacles standing in the way of sociological research, such as common sense conclusions (which frequently seem all too obvious), individualistic and naturalist conceptions, and of course the belief systems enshrined in organised bodies of doctrine that provide an impulsion towards a should be.

In conceptualising ethics as a sociological fact, we will make use of contributions from a variety of authors (particularly the classics of social theory) that have worked in the area of ethics or morals, or on similar themes, giving special attention to the rupture that they brought about with philosophical and theological approaches to the subject (Marivoet 2007): i) the historical contextualization of established principles; ii) an assessment of the extension, regularity and orientation of the different acts that undermine them; iii) the nature of cooperation or solidarity expressed in a particular social figuration (in this case, the sports figuration); iv) the various tensions that pervade them and point out, if possible, the tendencies of changes. These are all in themselves extremely relevant for the study of this phenomenon.

We start out, therefore, from the assumption that ethics is an observable sociological phenomenon, in the sense that the fundamental principles orienting action in a particular historical context exert a palpable influence upon forms of cooperation or solidarity and the habits and customs arising from them. These are then established as rules of conduct, subject to mechanisms of imposition and transformation whenever profound social changes take place. We also consider that changes taking place in the realm of ethics may be observed in the processes that we call ethical regulation and regularization, understood as operative and methodological instruments that allow us to identify tensions and conflicts in expected behaviours. Our starting point will be established ethical principles, whose underlying meaning or connections of meaning we will try to comprehend, by seeking to understand the practices that broke with them, in the Weberian sense.

We have chosen Portuguese sport during the democratic state of the $20^{\text {th }}$ century as a case study, since this may function as a reference for the situation experienced in the broader space of sports figuration. As the country only became a democracy in 1974, following the overthrow of a fascist 
dictatorship, the changes that swept through modern societies during the $20^{\text {th }}$ century have only been evident since then.

As regards the discussion of facts, our aim was to investigate the extent to which increased competition and the affirmation of rival vested interests in the sport figuration, particularly in the field of top-level professional practice (especially football), have led to contradictions in the way in which established ethical principles determine practices, thus generating new dynamics, which in turn have contributed to the flexibilization of regulation, the undermining of ethical regularization and differentiation of cooperation (Marivoet 2007).

As research hypotheses, we consider that the increased competition for the best results in sporting competition has led to a greater involvement on the part of actors and organizations in ethical regulation, making it more negotiable, flexible and adaptable to the different vested interests that are at stake. We also consider that the dynamics generated by the affirmation and defence of different vested interests create conflict, a dimension which undermines ethical regularization.

We suggest, therefore, that the assertion of different interests may have led, on the one hand, to the appearance of acts that break with the ethical principles, including those intended to bolster the vested interests of one group at the expense of another (such as the breakdown of fair play, including manifestations of hostile or violent rivalry, doping, corruption, etc. - the extent and regularity of which we do not yet know); and, on the other hand, to new lines of conflict, such as manifestations of violent revolt, which may have resulted from power imbalances, senses of injustice and from the establishment of a general climate of distrust between sporting agents, organizations and regulatory bodies. It will be important to discover exactly what those are and how they are expressed.

We have also considered that there will have been a tendency for ethical principles to harden into regulations, enforced through the organized imposition of repressive sanctions. There will probably also have been a successive tightening-up of the framework of penalties and sanctions, which may in turn have led to new conflicts. In this case, we need to know exactly what those are and in what contexts they have occurred, and also if the measures implemented will have contributed to ethical regularization.

Finally, we hope to find out if the dynamics resulting from increased competition and the affirmation of rival vested interests, particularly in the field of professional practice and top competition (and especially football), have contributed to the differentiation of cooperation. Cooperation may, on the one hand, be reinforced and gain cohesion within same-interest groups with increased confrontation-opposition; it may thus assume forms of mechanical solidarity, while on the other hand, becoming more strategic in situations of negotiation, thereby reinforcing contingent solidarities at the expense of organic solidarities.

\section{The processes of ethical regulation and regularization as operative-methodological instruments}

We consider that changes taking place in the realm of ethics may be observed in the processes that we call ethical regulation and regularization, understood as operative-methodological instruments that allow us to identify tensions and conflicts in expected behaviours. Our starting point will be established ethical principles, whose underlying meaning, or connections of meaning, we will try to comprehend, by seeking to understand the practices that broke with them, in the Weberian sense.

However, the social processes through which ethics may be observed should not be confused with the reality itself. Those processes merely indicate the mechanisms with which the institutionalized principles are reproduced at a particular historical moment, the conformity of practices that give them shape, or the conflicts that arise out of practices that infringe them. Thus, ethics should not be confused with the range of normative mechanisms that exist to control behaviour and penalize misconduct, since these are merely regulatory tools located in time and space, as Weber pointed out (2001 [1912], p. 31). 
In the changing context of late-modern advanced-capitalist societies, there has been an intensification of competition in many different spheres of social life accompanied by increased reflexivity (Elias 1993 [1939-1987], Touraine 1994, 1996, Giddens 1994, 1995, Beck et al. 2000, Delanty 2000, Sennett 2001). There is also an authoritarian strictness about the regulatory action taken to control behaviours (Weber 1990 [1905], Foucault 1986 [1975], Goffman 1993 [1956]). In such a context, we are justified in wondering if the ethical tensions we observe may not be associated with the contradictions emerging from that very situation. In other words, we ask ourselves to what extent the rupture with the modern re-elaboration of the traditional disciplinary ethos (i.e. inflexible authoritarian regulatory action oriented towards hierarchical obedience), clearly evident in sports organizations, as Brohm (1992) and Hargreaves (1998a) have pointed out, can be seen in sports figuration. Thus, our aim is to discover whether the increased involvement of the actors in ethical regulation will have contributed to a greater flexibilization of the system, and if so, what conflicts might have emerged from that.

Bearing in mind that ethics is subject to change, as we have said, and that social figurations are permeated by power relations and tensions (such as those arising from collective and individual vested interests), an analysis of the process of ethical regularization must take into account the contexts in which established ethical principles are infringed and the forms that these transgressions take. This will enable us to understand the significance (in Weber's terms, the object of apprehension or subjective sense) of the weakening of these principles.

As regards the undermining or weakening of ethical regularization, this could take various contradictory forms. For example, it may indicate the bolstering of one group's interests at the expense of the other (or indeed, deliberately against the other); or it may express the claims of other interested parties (individuals, groups or organizations) whose influence is underestimated or not immediately observable in the balance of power within a particular social figuration. It may even result from some maladjustment or contradiction in the established principles themselves, in view of the social change taking place in societies.

Thus, if we speak of the undermining of ethical regularization, this is not to imply that there are no ethics at all (as common sense might suggest, or as has been represented in some bodies of doctrine or theory, such as described by Boudon 1990, 2002); we can, however, speak of a "breakdown in cooperation'. As Weber argued (1989 [1904], p. 608), the "judgment of the validity" of the sense that actors give to an action falls into the realm of "belief" and therefore has no place in an empirical science like sociology. Durkheim also argued that to study morals as they appear to us, we have to "bracket off the ways of seeing and judging" that we have acquired through tradition, using the Cartesian "discipline of methodical doubt" - not discussing morality, but rather the interpretations that are made of it (1977 [1893], p. 48).

\section{Forms of cooperation or types of solidarity: mechanical, organic and contingent}

Given the tendency for change amongst increasingly interdependent societies, social relations have become more strategic, determined by belief in a system of gains and losses (Elias 1989, 1990 [1939], Mannheim, s.d.a/b [1928], Goffman 1993 [1956], Mills 1981 [1956], Crozier and Friedberg 1977, Bourdieu 1994a, 1997, Giddens 1994, 1995, Touraine 1994, 1996, Mintzberg 2004). In such a context, we might expect different forms of cooperation to be found, observable in types of solidarity, although understood as the ideal type in Weber's terms (2001 [1912]).

For this purpose, the notions introduced by Durkheim (1977 [1893]) would seem to be particularly pertinent, namely mechanical solidarity (bonds between bearers of similar common values) and organic solidarity (agreements based upon the functional interdependence of individuals). These are, however, understood as operative notions for analysis, precisely because we have conceived of them as an ideal type of approximation to the real, adding a third notion, which we will call contingent solidarity (short-term alliances between individuals with strategic interests). Thus, we 
are moving away from Durkheim's normative approach to morality, particularly the axiological polarity between solidarity and anomy, which, in the structural-functional or functional paradigms of Parsons (1976 [1959]) and Merton (1970 [1949]) took the form of dichotomies such as 'integration/anomie', 'function/dysfunction' and 'order/deviation' (Besnard 1987).

\section{The homo ethicus}

As other authors have argued (e.g. Bauman 1997, Alberoni 1997, Giddens 2000), we also assume that solidarity requires not only a rational or functional dimension but also an affective one, particular to us as human beings. Starting from the assumption that social (human) action may not be understood on the basis of a rational/emotional duality, it would seem plausible to speak of solidarity in the establishment of any form of effective cooperation. Precisely because a human being is a rational and affective animal with a natural inclination to associate with those of his kind (also through demarcation or opposition to others), we may call him homo ethicus.

Thus, we are moving away from Weber, for whom solidarity served the purpose of "community constitution" (Vergemeinschaftung), based upon what he called "felt solidarity (affective or traditional)" between participants, as opposed to other forms of cooperation such as "society formation"(Vergesellschaftung), i.e. "the adjustment of interests for rational reasons" (axiological or teleological in character) or unions of common interest. As Edgar Morin (1984, p. 118) argues: "To conceive of the dual nature of society's gesellschaft/gemeinschaft, we must abandon the disjuncture between the two notions (which are complementary, even as they oppose each other) and the reduction of the idea of society into one or another of them".

In fact, the wide range of studies in the field of sociology of sport, pioneered by Norbert Elias and Eric Dunning (1986), has demonstrated the powerful emotional investments in the solidarities produced around nation-states, represented by the respective national teams. This is clearly visible in large-scale international sporting events such as the Olympic Games (Hargreaves 1998b, Roche 2000), world or continental football championships like the 1998 World Cup in France (Dauncey and Hare 1999) and the 2004 European Cup in Portugal (Marivoet 2006a,b), and also in tournaments between city or regional clubs (Maffesoli 1988, Dunning 1999, Giulianotti 2000, Armstrong and Giulianotti 2001, Giulianotti and Finn 2000, Dunning et al. 2002).

\section{Research strategy}

For the purpose of testing the research hypotheses or research methodology, our model of analysis is structured into four dimensions, separated into variables, each of which is in turn divided into indicators: - i) Nomos of Modern Sport - Corpus of Accepted Beliefs and Established Ethical Principles; ii) Ethical Regularization - Ethos (disciplinary authority, actor involvement, levels of conflict and conciliation); iii) Undermining of Ethical Regularization - Practices Incurring Sanctions (breakdown of fair play, doping and corruption) and Actors' Subjective Sense; iv) Cooperation, Demarcation and Opposition - Types of Solidarity (organic, mechanical and contingent), Trust and Violence (contexts, forms, protagonists) (Marivoet 2007).

In the observation of empirical reality, priority is given to facts that are in the public domain and therefore discussed in the media; also, the participative observation at football matches from amongst Premier League "claques" (groups of ultra fans), and interviews with some of their leaders; legislation and regulations of sporting organizations; statistics prepared by the National Anti-Doping Council/Agency and the security forces, and a series of statistics based upon the decisions of the Disciplinary Body of the Portuguese Football Federation over the course of three seasons, selected from each decade.

By analysing incidents that took place in Portuguese sport over three decades of the democratic state (between the end of the 1973/74 and 1999/00 sports seasons), it has been possible to interpret the 
situation in an interlinked fashion, as proposed by Elias (1980), achieving an order of intelligibility of the analysed empirical reality essential for the comprehension of facts, despite the difficulties raised by the enormous quantity of information to be processed.

\section{Changing values and principles of the modern sport}

Broadly speaking, the facts point to a radicalisation of the ideals of modern sport, expressed in the Olympic motto altius citius fortius. This is visible in alterations to the nomos (constitutive principle) of the field of competitive practices (Bourdieu 1987, 1994a), especially in the area of professional sport, and football in particular. Ruptures have been produced in the underlying value structures and this leads to contradictions in the way in which established ethical principles affect practices.

Those principles derive from the ideals that presided at the advent of Modernity, such as fair play or the "sporting spirit", which established cooperation and loyalty as the basis of sporting competition (though the connotations of gentlemanly behaviour and virtuous character were acquired from the aristocratic ideology, particularly as regards respect for rules and hierarchies); fairness in competition, based on merit associated with effort and the work ethic implicit in training, alongside talents such as skill or audacity; and the freedom of sports associativism in civil society, i.e. the autonomy of sporting associations as regards their organization and regulation, and the promotion of a competitive framework for the different sports. The standardization of sports and the constitution of associations to organize and regulate competition also reflected the political forms of organization of states of law, as Elias and Dunning (1986) has pointed out.

Therefore, despite the fact that the institution of modern sport is a social space considered to be a world apart from real life, given its recreational and amateur character, it nevertheless mirrors social life. The first visible impact of the changes taking place was the demise of the amateur principle in international associative sport at the start of the final quarter of the $20^{\text {th }}$ century, which led to the development of the dimension of performance and the commodification of the spectacle, within a social context of globalization of markets and lifestyles. This situation has created unintended alterations in the nomos of the field of competitive practices, inextricably linking the sporting, economic and symbolic dimensions and determining a victory-oriented approach to the action. This in turn led to an intensification of competition and a radicalisation of interests in the results.

\section{Dynamics of the sports market and tendencies}

Throughout the period under analysis, economic questions have become increasingly important for Portuguese sports organizations. This has resulted both in new forms of cooperation (thus reinforcing organic solidarities) and in a breakdown or weakening of them, caused by conflicts in associative sport and between this and the state, leading to the creation of other forms of cooperation based upon mechanical or contingent solidarities. Although this has acquired a higher profile and greater incidence in the field of professional practices, particularly football, due to the large investments needed to acquire the best players and coaches at international market prices, it has also extended to competitive practice in general, since the costs of producing a sporting performance mean that sports organizations have to make efforts to gather financial resources.

Professional sport is thus subject to market forces. Competition results are inevitably linked to the capacity to attract financial resources, either through public subsidization or private income generated by the commodification of the sporting spectacle (Rigauer 1993, Dunning 1999, Giulianotti 2000, Andreff and Nys 2001, Charrier 1995, Chifflet 2001). This in turn is connected to the symbolic dimension, since the generation of financial resources is dependent upon the existence of a clientele (fans, the public); on whose back come the media, and sponsors, and public bodies interested in 
investing in sport as a symbol of national or local representation (Marivoet 2002b, 2006a,b, Roche 2000, Horne \& Manzenreiter 2006).

\section{Contradictions in ethical principles as result the victory-oriented sporting action}

This victory-oriented approach to sport necessarily meant that maximum returns were expected from investments in athletes through the provision of the best possible training conditions, something that would only be possible with financial resources. One of the unintended consequences of this has been the weakening or devaluing of the work ethic, which had been enshrined as an ethical principle in the value structure underlying training in modern sport, and this led to contradictions, particularly as regards the principle of fairness in competition.

As economic resources gradually became more and more essential for ensuring maximum output from athletes, it is not difficult to see that conditions were being created for the development of new means to achieve the same end, such as through the use of performance-enhancing substances and methods, even when the health of the athletes was at risk. The need thus arose for sporting organizations and states to impose limits on doping practices, by setting up inspection procedures and imposing sanctions on offenders.

\section{Doping practices and regulation}

These procedures were adopted by the Portuguese state beginning in the 1980s, though the legislation took time coming into effect, given the commitments assumed within the Council of Europe. By the end of the period under analysis, the international struggle against doping in sport had gained a new impetus. The World Anti-Doping Agency (WADA) was set up in 1999, upon a motion put forward by the EU together with the IOC, which in turn proposed the establishment of the UNESCO International Convention against Doping in Sport in 2005.

The objective of the world anti-doping programme, as defined by the World Anti-Doping Code version 3.0 of February 2003 and adopted by the IOC as an annex to the Olympic charter, is 'to promote health, fairness and equality for athletes worldwide'. Naturally, one of the effects of labelling a given behaviour as illicit is that infraction compromises the principle of fairness in competition, causing it to be viewed as disloyal behaviour.

Nevertheless, the question is by no means straightforward. For many people, it seems unreasonable to ban the use of certain performance-enhancing substances or methods in the interests of fairness, even when they do not harm the health of the athletes, while tolerating the existence of differentiated training conditions arising from different economic possibilities (König 1995, Volkwein 1995, Ferstle 2001).

Moreover, as regards athletes' health, it is also contradictory that performance-enhancing substances and processes are banned on the grounds that they may be harmful, while no measures are taken to limit the damage caused by excessive physical loads during training, as can be seen in the literature about injuries sustained during sporting activity (Waddington 1996, 2001).

In Portugal, there has been an increase in anti-doping controls since the mid-1980s, both in terms of the sports affected and types of tests performed. The average number of positive cases during the 1990 s was $0.74 \%$, while by the last three years of the period under analysis (1998-2000) it had risen to $1.4 \%$, revealing a undermining of ethical regularization, and this tendency continues during the present decade (Fig. 1).

Following international commitments, there was a reinforcement of control and sanction in 2009 by the Portuguese State (Law No. 27/2009 of $19^{\text {th }}$ June). As we see, the facts that anti-doping measures have proved ineffective is due not only to difficulties in controlling the practice; the main obstacle is clearly the demand that exists for such substances and the constant discovery of new ones 
which satisfy that demand. Consequently, the official list of banned substances and processes can never keep up the range of possibilities on offer on the world market.

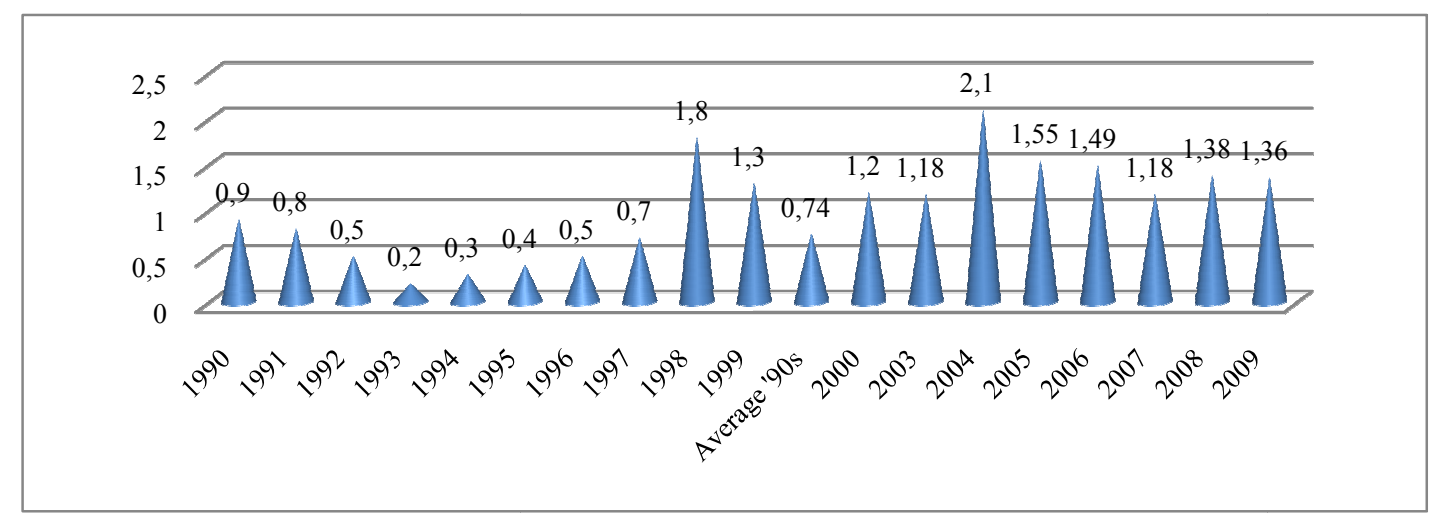

Figure 1. Violations of the anti-doping rules (\%)

Source: Horta 1999; CNAD - National Anti-Doping Council and ADoP - Portuguese anti-Doping Agency

\section{Weakening the principle of fair play}

The increased competition arising from changes to the nomos of the field of competitive practices has also weakened the principle of fair play. This becomes more intelligible if we remember that the various competing interests around the matter of match results have produced alterations in the ethos of sporting interaction. Athletes are now urged to play at the very limit of the rules or even in the margins of them, as Elias and Dunning (1986) have shown, thereby contradicting the cooperation and loyalty required by the principle of fair play, and producing behaviours that frequently flaunt that principle.

Based upon the decisions taken by disciplinary bodies in Portuguese football (since more information is available about football than about other sports), we estimate that the number of footballers incurring sanctions went up from 3.2\% to $9.5 \%$ between the $1970 \mathrm{~s}$ and the 1980s. Although it is not possible to compare these figures with statistical information for the 1990s, there was during that period (1993/94 to 1995/96) an annual average increase of around $37.8 \%$ in suspensions of players in national matches, while the total number of sanctions incurred rose by about $6 \%$, revealing an increase in the number of penalties imposed by disciplinary bodies. This growing trend for acts that undermine the principle of fair play is also manifested in district tournaments. The number of incidents in which the Republican National Guard (GNR) was forced to intervene (category 'violence between or caused by players', in matches that were mostly football and policed in predominantly rural zones) rose by an average of 7.5\% per year between 1993 and 2000 .

However, the change in the ethos of sporting interaction has also caused problems for regulation, particularly in sport-games. In football, at least, latent tensions have been released concerning the fairness of referees, leading to the establishment of a climate of distrust, and manifestations of violent nonconformism (on the part of players, other sporting agents and the general public) and an increase in acts that contribute to the undermining of ethical regularization and once again undermine the principle of fair play. At least in football, the action of regulatory bodies in imposing sanctions upon such practices has generated a dynamic of surveillance and supervision, and these have become ever more pressurised and participated spheres of negotiation. Increased involvement of sporting agents, who use both institutional means ('protests' and 'appeals' to regulatory bodies) and other forms of pressure and persuasion, has contributed further to the flexibilization of ethical regulation.

This situation has been particularly marked in football, as the public has gradually become aware of expedients arising from corruption to control results (such as the bribing of referees, players and heads of federation bodies), thereby discrediting regulatory bodies and leading to the installation 
of a generalized climate of distrust. This elucidates a growing distrust between individuals, and between individuals and institutions, as has been pointed out by a number of authors (França 1993, Giddens 1994, 1995, 1997, Bourdieu 1997, Sennett 2001).

\section{Corruption, distrust and dynamics of surveillance and supervision}

In Portugal, with the criminalization of corruption in sport in October 1991, there has been an increase in public awareness and in the number of cases being investigated by the criminal police $(\mathrm{PJ})^{1}$. Before then, the absence of any proof had often led to the sanctions being imposed upon sporting agents by the regulatory bodies, leading to contention about many of the denunciations made.

In this process, the media has come to play a central role, as in other social domains (Thomas 1993, Roche 2000, Giulianotti 2000, Esteves 2003, Vidal 2004). It provides a stage for the denunciation or defence of suspected cases of corruption, giving different agents a voice in the process; and also undertakes its own investigative journalism, adopting a panoptic protagonism in the dynamics of surveillance and supervision, particularly as regards refereeing practices. However, it would seem that this process is related more to own interest, particularly as the exposure of cases from top-level national football clubs ensures increased sales and ratings, and therefore a vast audience. Moreover, there have also been instances of aggression against news reporters, not to mention cases of blackout, which suggests a certain lack of impartiality in the way these matters are treated by the media.

An alteration in football refereeing methods that took place in the middle of the 1990s ("if in doubt, don't whistle") also contributed to the flexibilization of the rigid ethos of normative or disciplinary orientation to the rules of the game. Although its aim was to reinforce the spectacle arising from difficulties imposed by the alteration of the competition ethos or revive the vigour and balance of tension in games, as Elias and Dunning (1986) point out, it ended up producing contradictory effects. Credible justifications were found for referee errors, a situation that was reinforced by FIFA's prohibitions on the use of video playback to assess technical errors; this then fuelled the perceived sense of injustice, aggravating distrust and leading to increased surveillance and supervision, and violent acts of revolt.

\section{Violence and hostilities}

Despite the successive tightening-up of the legal framework that controls and penalizes violence in sport, and enhanced police intervention, the 1990s saw an increase in incidents registered by security forces (Fig. 2). There was an average annual increase of $2.3 \%$ between 1993 and $2000^{2}$, and between 2000 and 2008, an average annual growth of incidents was registered at $1.66 \%$. Also in 2009, there was a reinforcement of control and sanction of violence, racism, xenophobia and intolerance in sport (Law No 39/2009 of $30^{\text {th }}$ July). These facts suggest that the measures adopted to control violence in sport have been largely ineffectual, and even counter-productive. The level of repression has been inadequate to deal with the phenomenon, as can be seen from the increase in confrontations between fans and the police (an average annual increase of 3.6\% between 1993 and 2000).

\footnotetext{
${ }^{1}$ There was a reinforcement of control and sanction of corruption in sport in 2007 (Law No 50/2007 of $31^{\text {st }}$ August).

${ }^{2} 1.2 \%$ of policed matches in continental Portugal, Madeira and the Azores were marred by incidents involving violence in 2000. Most of these occurred in urban areas within the metropolitan districts of Lisbon and Oporto, which accounted for $69 \%$ of cases (an incidence rate of $1.3 \%$ ) In $2000,0.78 \%$ of the incidents that occurred were in football (11), and of the remaining $22 \%, 12 \%$ were in 5 -a-side football and $2 \%$ in futsal. Although this means that only $8 \%$ accounted for other team sports like roller hockey $(3 \%)$, handball $(2.5 \%)$, basketball $(2 \%)$ and field hockey $(0.3 \%)$, the data nevertheless reveals that the phenomenon has been gaining expression in different kinds of collective sports.
} 
There has generally been a diversification as regards targets of violence, with referees no longer the main targets (although between 1993-2000 there was an estimated annual increase of $1.7 \%$ in assaults or attempted assaults upon them, constituting 33\% of occurrences recorded by the security forces). In 2008, assaults on referees accounted for $29 \%$, of the total of incidents. The highest number of incidents was in the item 'diverse occurrences' (37\%), that also covered occurrences outside the stadium.

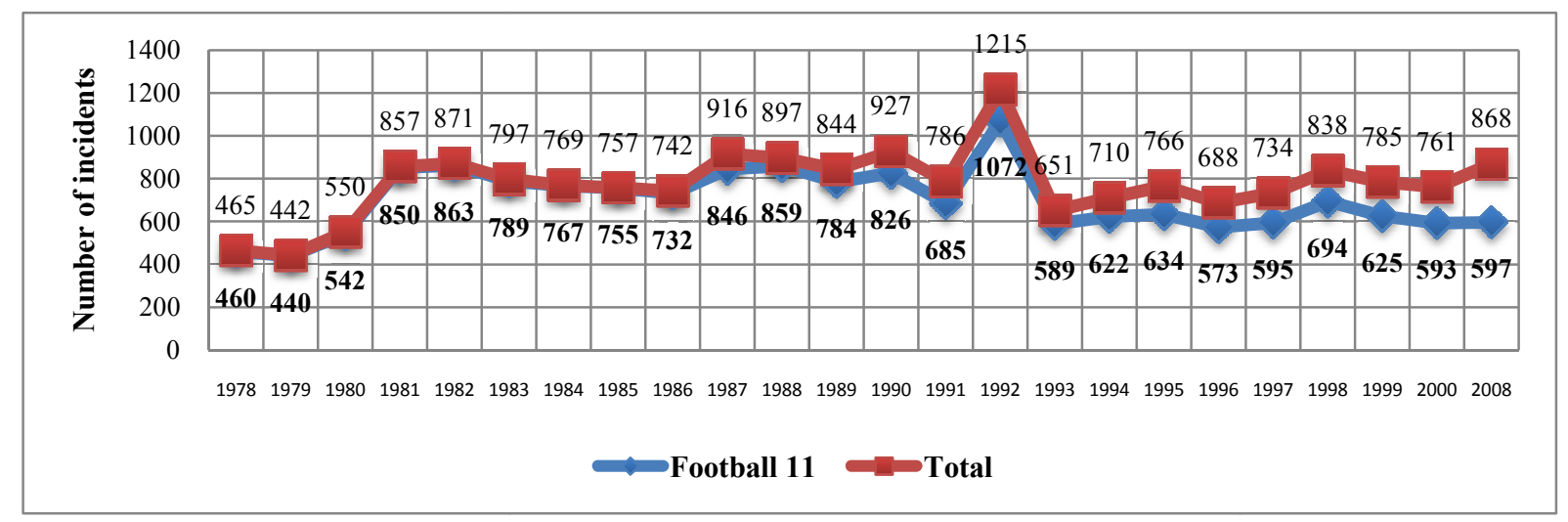

Figure 2. Evolution of violent incidents at policed games (1978-2008)

Source: Annual report of the Portuguese security forces (PSP and GNR)

The stages of violence have also diversified as a result of the strong police presence inside stadiums, the physical protection of agents on the pitch, CCTV surveillance in some stadiums, and sanctions imposed upon clubs found to be in breach. There have also been changes in the forms taken by violence, largely resulting from the increased security measures, with a displacement of incidents to outside the stadiums (Brown 1998, Stott et al. 2001, Dunning et al. 2002, Marivoet 2006a).

However, some manifestations of violence in top-level professional football have started to become independent of championships. The facts suggest that some ultra groups have become the self-appointed "guardians" of their clubs' colours, which they are prepared to defend "to the end", deliberately stirring up hostile rivalries and giving shape to the simmering distrust that exists between opponent groups. The violence, unleashed by their respective leaders and broadcast by the media, takes the form of aggression against fans from rival clubs or their property (within geographic proximity), ambushes (known 'esperas') and generalised brawls. Nevertheless, the facts suggest that, as regards Portugal's most prominent teams, ultra violence is unlikely to have contributed greatly to any breakdown in cooperation between the clubs, even though such incidents have been used as leverage by managers in the successive disputes that have taken place in the public domain, especially in the second half of the 1990s.

The hostilities between some groups of ultras have tended to intensify, as regards the forms of violence used, and in some cases there has been extreme brutality leading to tragic consequences. The ultra mentality has incorporated traditional male values, which are then associated with stereotypes such as the devoted fan and the militant, thereby creating conditions for further violence. The conflicts that flare up between them constitute a kind of leitmotif for the autonomous reproduction of violent rivalries that are driven by mechanical solidarities, a situation that has been manifested in other societies with both ultra and hooligan/casual subcultures of fans (Podaliri and Balestri 1998, Roumestan 1998, Armstrong 1998, Armstrong and Giulianotti et al. 2001, Dunning et al. 2002, Hourcade 2002, Marivoet 2002a, 2006a).

\section{Loss of autonomy of sports organizations}

Finally, mention should also be made of the complexity of tensions and conflicts arising in the field of sport, and which have required public intervention, in some cases involving joint 
intergovernmental action, such as those constituted by the European Conventions under the Council of Europe. This has led to a successive loss of autonomy on the part of sports organizations, thus contradicting the principle of freedom of sports associativism in civil society. This is exemplified in the 'Bosman case', especially the important role played by the Court of Arbitration for Sport (CAS) set up by the IOC in 1983. In the wake of this, FIFA also set itself up as a court of appeal for the resolution of disputes between football clubs over the transfer of international players.

However, in Portugal, there have been some cases in which sporting disputes have been settled in civil courts. This became possible in 1990 for situations considered to be "strictly sports-related", but has led to breakdowns in cooperation, since FIFA and its continental and national associates prohibit such a recourse, as became clear in the so-called 'Mateus case' (name of a player) in the 2006/07 season.

Considering the relationship of interdependence established between the sporting, economic and symbolic dimensions in contemporary or 'late modern' sport, we can perhaps expect an increase in supranational jurisdiction in each federation, as a way of preserving the principle of autonomy of association in international sport, with the Court of Arbitration for Sport becoming the court of final appeal for sports organizations.

Although it is unlikely that sporting organizations will regain the autonomy that they enjoyed in modern sport during the $19^{\text {th }}$ century, precisely because of the changes that have taken place during the course of the $20^{\text {th }}$ century, we might hope that many of the tensions and conflicts could be reduced by increased negotiations and settlements between the organizations and public bodies. However, given the transnational character of sport, this is likely only to become truly effective on an intergovernmental level.

In the European Union, the importance of the autonomy of sports organizations was acknowledged by the Declaration of Nice of the European Council, approved in December 2000, and the Treaty of Lisbon. Also there have already been attempts on the part of European sports associative movement to set up platforms for negotiation with European Commission bodies, and recently, there has been signs of a response. Thus, it would seem that this situation reflects the present tendency to reinforce the reflexivity of social actors (cf. Beck et al. 2000) and to search out more participated forms of regulation or citizenship (Giddens 1997, Ladrière 2001, amongst others).

\section{Final remarks}

To conclude, we aim to show how the intricate interdependence between the sporting, economic and symbolic dimensions of late modern sport has given rise to an intensely victory-oriented approach in the field of competitive practices, with the consequent radicalisation of competing interests and an intensification of competition. This has led, firstly, to a series of chain reactions that have weakened the ethical values upon which modern sport was traditionally based, leaving them ill-equipped to effectively determine practices, and secondly, to the development of alternative strategies for controlling results that subsist on the margins of institutional methods.

In this context, there have been changes in the ethos of sporting interaction, weakening the principle of fair play and leading to an increase in practices that undermine it. This has meant that refereeing has become much more difficult, with increased distrust in the fairness of the competition, a situation which is aggravated by cases of corruption and doping. In this context, actors and organizations have become more involved in the ethical regulation of their sport. As a result, regulation has become more flexible and open to negotiation, both through institutional channels, and through strategies of pressure and persuasion in the (highly mediatized) public sphere. Thus, contingent solidarities have been strengthened to the detriment of organic solidarities.

The growing distrust, together with the dynamics of surveillance and supervision launched in the 1990s, have also contributed to the activation of mechanical solidarities within groups with shared 
interests, in a context of opposition-confrontation or radicalization. This has been conducive to manifestations of collective violent revolt, and to the institution of forms of premeditated violence between some groups of ultra fans. Consequently, the undermining of ethical regularization has become even more visible, particularly in the field of top-level professional football.

As far as it is possible to tell from the facts collected, it would seem that the ethical conflicts analysed in our research are not exclusive to professional football (Marivoet 2007). Nevertheless, it is in the field of professional football that these issues are most pertinent. Precisely because the sporting spectacle is at its most commercialised and internationalised in football, the economic and symbolic stakes are very high and so the pressures to win are tremendous.

In response to the specific nature of the ethical conflicts in the sports figuration, states have intervened at national and European level by enshrining ethical principles in the form of legal provisions, defining systems of sanctions and penalties. This has resulted in a weakening of the autonomy enjoyed by sporting organizations, a principle that ultimately derived from the freedom of sporting associative movement in civil society.

Although our conclusions go some way towards explaining the issue, there is still much more work to be done, particularly in areas have not been thoroughly covered in this research. This research, then, forms our contribution to the sociological study of ethics in sport, a survey of some of the principles, practices and conflicts that affect sport in the form that it takes in contemporary society. It should be viewed as part of a broader process in which new questions are raised with every answer found, and in the current context of ongoing change, further study is still required before we achieve a more complete understanding of the phenomenon in question.

\section{REFERENCES}

Alberoni, F. (1997). Valores. Lisboa: Bertrand Editora.

Andreff, W., Nys, J.-F. (2001). Économie du Sport (4 ${ }^{\text {th }}$ ed.). Paris: PUF.

Armstrong, G. (2000). Football Hooligans. Knowing the score ( $2^{\text {nd }}$ ed.). Oxford: Oxford International Publishers.

Armstrong, G., Giulianotti R. (Eds.) (2001). Fear and Loathing in World Football. Oxford: Oxford International Publishers.

Bauman, Z. (1997). Ética Pós-Moderna. São Paulo: Paulus.

Beck, U., Giddens, A., Lash, S. (2000). Modernização Reflexiva. Política, Tradição e Estética no Mundo Moderno. Oeiras: Celta.

Besnard, P. (1987). L'anomie. Paris: PUF.

Boudon, R. (1990). O Lugar da Desordem. Lisboa: Gradiva.

Boudon, R. (2002). Déclin de la Morale? Déclin des Valeur? Paris: PUF.

Bourdieu, P. (1987). Choses dites. Paris: Les Éditions de Minuit.

Bourdieu, P. (1994a). O Poder Simbólico (3 ${ }^{\text {rd }}$ ed.). Lisboa: Difel.

Bourdieu, P. (1994b). Les jeux olympiques. Programme pour une analyse. Actes de la Recherche en Sciences Sociales, 103, 102-103.

Bourdieu, P. (1997). Razões Práticas. Sobre a teoria da acção. Oeiras: Celta Editora.

Brohm, J.-M. (1992). Sociologie politique du sport ( $2^{\text {nd }}$ ed.). Nancy: PUN.

Brown, A. (Ed.) (1998). Fanatics! Power, identity e fandom in football. London: Routledge.

Charrier, D. (1995). Les flux économiques structurants du marché du sport. In A. Loret (Coord.), Sport et management. De L'Éthique à la Pratique (pp. 553-575). Paris: Éditions Revue.

Chifflet, P. (2001). Sport professionnel et politiques sportives publiques: deux logiques antinomiques. In A. Menaut \& M. Reneaud (Orgs.), Sport de haut niveau. Sport professionnel en région(s) (pp. 65-78). Bordeaux: MSHA.

Crozier, M., Friedberg, E. (1977). L'Acteur et le système. Paris: Seuil. 
Dauncey, H., Hare, G. (Eds.) (1999). France and the 1998 World Cup: The National Impact of a World Sporting Event. London: Frank Cass.

Delanty, G. (2000). Modernity and Postmodernity. London: Sage Publications.

Dunning, E. (1999). Sport Matters. Sociological Studies of Sport, Violence and Civilization. London: Routledge.

Dunning, E., Murphy, P. \& Waddington, I. \& Astrinakis, A. E. (Eds.) (2002). Fighting Fans. Football Holliganism as a World Phenomenon. Dublin: University College Dublin Press.

Durkheim, É. (1977 [1893]). A Divisão do Trabalho Social. Lisboa: Editorial Presença.

Durkheim, É. (1991 [1895]). As Regras do Método Sociológico (4 ${ }^{\text {th }}$ ed.). Lisboa: Editorial Presença.

Elias, N. (1980). Introdução à Sociologia. Lisboa: Edições 70.

Elias, N. (1989, 1990 [1939]). O Processo Civilizacional (vol.1º , 2º. Lisboa: Pub. D. Quixote.

Elias, N. (1993 [1939-1987]). A Sociedade dos Indivíduos. Lisboa: Pub. D. Quixote.

Elias, N., Dunning, E. (1986). Quest for Excitement. Sport and Leisure in the Civilising Process. Oxford: Blackwell.

Esteves, J. P. (2003). A Ética da Comunicação e os Media Modernos. Legitimidade e Poder nas Sociedades Complexas (2). Lisboa: Fundação C. Gulbenkian.

Ferstle, J. (2001). World Conference on Doping in Sport. In W. Wilson \& E. Derse (Eds.), Doping in Elite Sport. The Politics of Drugs in the Olympic Movement (275-286). Champaign IL: Human Kinetics Publishers.

Finn, G. P. T. , Giulianotti, R. (Eds.) (2000). Football Culture. Local Contests, Global Visions. London: Frank Cass.

Foucault, M. (1986 [1975]). Vigiar e Punir. História da Violência nas Prisões (4 ${ }^{\text {th }}$ ed.). Petrópolis: Vozes.

França, L. (Coord.) (1993). Portugal, Valores Europeus Identidade Cultural. Lisboa: IED.

Giddens, A. (1994). Modernidade e Identidade Pessoal. Oeiras: Celta Editora.

Giddens, A. (1995). As Consequências da Modernidade. Oeiras: Celta Editora.

Giddens, A. (1997). Para além da Esquerda e da Direita. Oeiras: Celta Editora.

Giddens, A. (2000). Viver numa Sociedade Pós-Tradicional. In U. Beck, A. Giddens \& S. Lash, Modernização Reflexiva. Política, Tradição e Estética no Mundo Moderno (pp. 53-104). Oeiras: Celta.

Giulianotti, R. (2000). Football. A sociology of the global game (2 ${ }^{\text {nd }}$ ed.). Cambridge: Polity Press.

Goffman, E. (1993 [1956]). A Apresentação do Eu na Vida de Todos os Dias. Lisboa: Relógio D’Água.

Hargreaves, J. (1998a [1986]). Sport, Power and Culture (5 ${ }^{\text {th }}$ ed.). Cambridge: Polity Press.

Hargreaves, J. (1998b). Olympism and Nationalism: some Preliminary Considerations, International Review for the Sociology of Sport, 27 (2), 119-138.

Horta, L. (Coord.) (1999). Lutte contre le dopage dans le sport au Portugal en défense de l'athlète/Fight against doping in Portugal in defence of the athlete. Lisboa: SED.

Hourcade, N. (2002). Supporterism: Ultras and World of Football. In M. Comeron \& P. Vanbellingen (Coords.), Prevention of violence in football stadiums in Europe (pp. 43-41). Liège: Eurofan.

Ladrière, P. (2001). Pour une Sociologie de l'Éthique. Paris: PUF.

Maffesoli, M. (1988). Le temps des tribus. Le déclin de l'individualisme dans les sociétés postmodernes. Paris: La Table Ronde.

Mannheim, K. (s.d.a. [1928]). Sociologia do Conhecimento (vol. I, II). Porto: Rés Editora.

Marivoet, S. (2002a). Violent disturbances in Portuguese football. In E. Dunning et al. (Eds.), fighting fans. Football Hooliganism as a World Phenomenon (pp. 158-173). Dublin: University College Dublin Press.

Marivoet, S. (2002b). The Public at Football Stadiums/ Le public des stades de football. In M. Comeron \& P. Vanbellingen (Coords). La prévention de la violence dans les stades de football en Europe / Prevention of violence in football stadiums in Europe (pp. 22-28 / 24-30). Liège: Eurofan.

Marivoet, S. (2006a). Euro $2004^{T M}$ Um evento global em Portugal. Lisboa: Livros Horizonte.

Marivoet, S. (2006b). UEFA Euro $2004^{\mathrm{TM}}$ Portugal: The social construction of a sports mega-event and spectacle. In J. Horne \& W. Manzenreiter (Eds.), Sports Mega-Events. Social Scientific Analyses of a Global Phenomenon (pp. 127-143). Oxford: Blackwell Publishing.

Marivoet, S. (2007). Ética do Desporto - Princípios, Práticas e Conflitos. Análise sociológica do caso português durante o Estado Democrático do século XX. Lisboa: ISCTE-IUL.

Merton, R. K. (1970 [1949]). Sociologia. Teoria e Estrutura. São Paulo: Editora Mestre Jou.

Mills, C. W. (1981 [1956]). A Elite do Poder (4 ${ }^{\text {th }}$ ed.). Rio de Janeiro: Zahar Editores. 
Mintzberg, H. (2004). Le Management. Voyage au centre des organisations (2nd). Paris: Éditions d'Organisation.

Morin, E. (1984). Pour sortir du XXe siècle (2 $2^{\text {nd }}$ ed.). Paris: Coll. Points.

Parsons, T. (1976 [1959]). El Sistema Social (2 ${ }^{\text {nd }}$ ed.). Madrid: Biblioteca de la Revista de Occidente.

Podaliri, C., Balestri, C. (1998). The ultràs, racism and football culture in Italy. In A. Brown (Ed.), Fanatics! power, identity e fandom in football (pp. 88-100). London: Routledge.

Rigauer, B. (1993). Sport and the Economy: A Development Perspective. In E. Dunning, J. Maguire \& R. Pearton (Eds.), The Sports Process - A comparative and developmental approach (pp. 281-305). Champaign IL: Human Kinetics Publishers.

Roche, M. (2000). Mega-Events and Modernity. Olympics and expos in the growth of global culture. London: Routledge.

Roumestan, N. (1998). Les Supporters de Football. Paris: Anthropos.

Sennett, R. (2001). A Corrosão do Carácter. As consequências pessoais do trabalho no novo capitalismo. Lisboa: Terramar.

Simmel, G. (1986 [1918]). El Individuo y la Libertad. Ensayos de crítica de la cultura. Barcelona: Ediciones Península.

Stott, C., Hutchison, P., Drry, J. (2001). Hooligans' abroad? Inter-group dynamics, social identity and participation in collective 'disorder' at the 1998 World Cup Finals. British Journal of Social Psychology, 40, 359-384.

Touraine, A. (1994). Crítica da Modernidade. Lisboa: Instituto Piaget.

Touraine, A. (1996). O Retorno do Actor. Ensaio sobre Sociologia. Lisboa: Instituto Piaget.

Vidal, J. M. (2004). Justiça em Crise? Lisboa: Quetzal Editores.

Volkwein, K. A. E. (1995). Ethics and Top-Level Sport - A Paradox? International Review for the Sociology of Sport, 30 (3/4), 311-321.

Waddington, I. (1996). The Development of Sports Medicine. Sociology of Sport Journal, 17, 176-196.

Waddington, I. (2001). Sport, Health and Drugs. A critical sociological perspective. London: Spon Press.

Weber, M. (1990 [1905]). A Ética Protestante e o Espírito do Capitalismo (3 ${ }^{\text {th }}$ ed.). Lisboa: Editorial Presença.

Weber, M. (2001 [1912]). Conceitos Sociológicos Fundamentais. Lisboa, Edições 70.

AUTHOR'S ADDRESS: $\quad$ Salomé Marivoet

Faculty of Sciences of Sport and Physical Education

University of Coimbra

Estadio Universitario, Pav. 3

3040-156 Coimbra, Portugal

Email: smarivoet@sapo.pt 